\title{
閖 \\ KONSEP HERMENEUTIKA OTORITATIF KHALED ABOU EL-FADL
}

\author{
Muhammad Sofyan \\ UIN Sumatera Utara \\ ryanasofee@gmail.com
}

\begin{abstract}
Abstrak
Tulisan ini memaparkan secara kritis Hermeneutika Otoritatif Khaled Abou el-Fadl dalam membaca teks-teks keagamaan. Dari paparan tersebut didapati bahwa hermeneutika Khaled secara implisit mengandung semangat Gadamerian yang membaca teks secara subjektif. Walaupun ia membuat beberapa persyaratan bagi para pembaca, namun persyaratan itu tampak kontradiktif dan memberikan ruang interpretasi al-Qur'an dengan tidak memperhatikan mana yang bersifat tsawābit dan mutaghayyirāt, atau ushūl dan furū'. Kelemahan ini dapat dilihat ketika perangkat yang ditawarkan Khaled dipraktikan dalam membaca beberapa ayat-ayat hukum, dimana Khaled lebih mengedepankan rasionalitas daripada aturan-aturan wahyu yang dijelaskan oleh sunnah kenabian dan disepakati oleh Ijma'. Implikasinya seluruh interpretasi tidaklah bersifat final, namun relatif.
\end{abstract}

\begin{abstract}
This article analyses critically the authoritative hermeneutics of Khaled Abou el-Fadl in reading religious texts. The study finds out that the Khaled's hermeneutics implicitly contain the spirit of Gadamerian who read the text subjectively. Although he has made several conditions for the readers, they seem to be contradictory and result in a qur'anic interpretation model which pays no attention between tsawäbit and mutaghayyirāt, or Ushū and Fur $\bar{u}$ '. This weakness can be seen when the method offered is practiced in reading few verses regarding Islamic law, where Khaled emphasizes the use of rationality than the meanings of revelation described by the prophetic sunnah and agreed by consensus'. Consequently, the whole interpretation is relative and indecisive.
\end{abstract}

Kata Kunci: hermeneutika, otoritatif, teks. 


\section{A. Pendahuluan}

Khaled Medhat Abou el-Fadl (selanjutnya disebut Khaled) adalah salah satu pemikir Islam kontemporer yang menawarkan model pembacaan teks keagamaan yang dianggapnya otoritatif. Model pembacaannya tersebut banyak disebut oleh peneliti sebagai hermeneutika otoritatif yaitu sebentuk hermeneutika negoisatif dimana makna merupakan hasil interaksi yang kompleks antara pengarang, teks dan pembaca yang disana makna diperdebatkan didialogkan dan terus mengalami perubahan. Perangkat ini memiliki karakteristik Hermeneutika yang berbeda dengan hermeneutika double movement, ideal moral dan legal specific milik Fazlur Rahman; atau Nasr Hamid Abu Zaid dengan pembacaan produktif hermeneutisnya (al-Qirä'ah al-Muntijah) yang dibedakan dengan pembacaan repetitif (Qirä'ah Mukarrirah); atau Muhammad Sahrur dengan pembacaan heremeneutis kontemporer (Qirä'ah Mu'ashirah) yang bertumpu pada dialektika kaynūnah (being), sairurah (process) dan shairurah (becoming) atau Abdullah Saeed tentang ethicolegal text yang bertumpu pada anggapan dasar bahwa bahasa alQur'an adalah ethical-theological dan memperkenalkan pendekatan progressive Ijtihadi. ${ }^{1}$

Kalau boleh dikatakan model heremeneutika Khaled agak lebih lunak dalam membaca teks-teks keagamaan. Dalam beberapa pandangan, dia sangat mengapresiasi tradisi fiqh dalam Islam yang menjunjung tinggi perbedaan (ikhtilāf), dan pada sisi lain dia menggunakan teori-teori Barat yang diinternalisasi dengan cukup kritis. Lebih jauh, model pembacaan Khaled ini merupkan respon yang produktif terhadap fatwa-fatwa dari lembaga hukum Islam, khususnya dari golongan Wahabi yang dianggap bersifat otoriter. Oleh karena itu, Khaled menawarkan sebuah perangkat operasional dalam menafsirkan teks atau memaknainya khususnya dalam menghasilkan sebuah hukum. Namun demikian, sebagai model baru, model pembacaan ini perlu ditela'ah secara kritis: apakah Heremeneutika Khaled tersebut sesuai dengan tradisi penafsiran dalam Islam? Apakah ia bisa menjadi solusi atas penafsiran yang

${ }^{1}$ Abdullah Saeed, Interpreting the Qur'an: Towards a Contemporary Approach (London and New York, Routledge, 2006), h. 123. 
otoriter? Bagaimana implikasi perangkat ini apabila digunakan dalam membaca teks keagamaan?

\section{B. Biografi Singkat Khaled Abou el-Fadl}

Nama lengkapnya Khaled Medhat Abou el-Fadl, populer dengan nama Khaled Abou el-Fadl. Ayahnya bernama Medhat Abou el-Fadl dan ibunya Afaf el-Nimr. Lahir di Kuwait pada tahun 1963. Sebagaimana masyarakat Arab pada umumnya, Khaled sedari kecil telah dididik dengan ilmu-ilmu keislaman. Al-Qur'an, Hadits, Bahasa Arab, Tafsir, dan Tasawwuf telah diakrabinya sejak dari sekolah pendidikan dasar. Ketika masih muda ia dikenal sebagai anak yang cerdas. Pada usia 12 tahun, ia sudah hafal al-Qur`an. Semasa kecil selain aktif mengikuti kelas al-Qur'an dan Syari'ah di masjid lokal di daerahnya, al-Azhar, dia juga mempelajari semua koleksi buku orang tuanya yang berprofesi sebagai pengacara. ${ }^{2}$

Pada waktu mudanya Khaled adalah seorang aktivis gerakan Wahabi yang merupakan mazhab negara Kuwait. Namun ia kemudian memutuskan untuk menetap di Mesir setelah dia menyadari adanya kontradiksi dan persoalan akut di dalam konstruksi ideologis pemikiran kaum Wahabi. Khaled memperoleh gelar B.A. (Bachelor of Art) di Yale University, Amerika Serikat (1986). Setelah itu ia melanjutkan ke University of Pennsylvania dan selesai pada tahun 1989. Dan pada tahun 1999, dia melanjutkan ke Princeton University dengan spesialisasi dalam bidang Islamic Studies dan pada saat yang bersamaan ia menempuh studi hukum di Universitas California Los Angeles (UCLA).

Di UCLA pula, ia ditunjuk sebagai guru besar hukum Islam dengan mengampu sejumlah mata kuliah, seperti hukum Islam, imigrasi, HAM, dan hukum keamanan nasional dan internasional. Selain di UCLA, Khaled juga mengajar hukum Islam di universitas Texas dan Universitas Yale. Selain aktif mengajar di sejumlah universitas prestisius di dunia, ia juga mengabdikan dirinya dalam bidang advokasi dan pembelaan HAM, hak-hak imigran, dan mengepalai sebuah lembaga HAM di Amerika. Pada tahun 20032005, Khaled diangkat oleh George Walker Bush Presiden Amerika

${ }^{2}$ Abid Rohmanu, Konsepsi Jihad Khaled M. Abou El Fadl dalam Perspektif Relasi Fikih, Akhlak dan Tauhid, Disertasi, (Surabaya: IAIN Sunan Ampel, 2010), h. 25. 
Saat itu - sebagai salah satu anggota Komisi Internasional Kebebasan Beragama (Internasional Religious Freedom). Di samping itu, Khaled juga sering diundang sebagai narasumber di radio dan televisi, seperti CNN, NBC, PBS, NPR, dan VOA.

Adapun karya-karya Khaled diantaranya adalah a) The Search for Beauty in Islam: A Conference of the Books (Lanham, Md: Rowman and Littlefield, 2006), b) The Great Theft: Wrestling Islam From the Extremists (San Francisco, Ca: HarperSanFrancisco, 2005), c) Islam and the Challenge of Democracy (Pricenton University Press, 2004), d) The Place of Tolerance in Islam (Cambridge University, 2001), e) Rebellion and Violence in Islamic Law (Cambridge University, 2001), f) Speaking in God's Name: Islamic Law, Authority, and Woman (Oneworld Publication, 2001), g) And God Knows the Soldier: The Authoritative and Authoritarian in Islamic Discourse (2001), dan h) The Authoritative and Authoritarian in Islamic Discourse: A Contemporary Case Study (Washington: Al-Saadawi Publisher, 2002).

Selain menulis buku, Khaled memiliki paper kuliah yang berjumlah ratusan dan artikel di media massa yang tak terhitung. Produktivitas menulisnya sangat jelas didukung oleh penguasaan yang luas atas khazanah klasik Islam dan keilmuan kontemporer.

\section{Problem Otoritarianisme: Latar Belakang Kemunculan Gagasan}

Otoritarianisme merupakan istilah yang mengacu kepada sebuah tindakan otoriter yaitu bertindak dengan sewenangwenang. ${ }^{3}$ Dalam bukunya "Speaking in God's Name: Islamic Law, Authority, and Women", Khaled menjelaskan bahwa otoritarianisme merupakan pengabaian terhadap realitas ontologis Tuhan dan pengambilalihan Tuhan oleh wakil Tuhan sehingga wakil tersebut secara efektif kemudian mengaju kepada dirinya sendiri. Tindakan demikian berimplikasi pada penolakan integritas petunujuk teks dengan menutup kemungkinan bagi petunjuk-petunjuk tersebut untuk mengungkapkan dirinya sendiri, dan menghalangi perkembangan dan evolusi makna komunitas interpretasi. ${ }^{4}$

${ }^{3}$ Kamus Bahasa Indonesia, (Pusat Bahasa Departemen Pendidikan Nasional: Jakarta, 2008), h. 1025.

${ }^{4}$ Khaled M. Abou Fadl, Atas Nama Tuhan: Dari Fikih Otoriter ke Fikih Otoritatif, 
Menurut Khaled tindakan demikian telah mewabah pada masyarakat Muslim kontemporer, dimana para ahli hukum telah melakukan penafsiran yang otoriter terhadap teks-teks al-Qur'an dan tradisi kenabian. Pasalnya kondisi ini dalam pengamatan Khaled telah terjadi semenjak tahun $1975 .{ }^{5}$ Baginya, para tokoh agama tidak lagi berbicara tentang Tuhan (bukankah teologi, secara etimologis, tidak lain adalah "berbicara tentang Tuhan"?), melainkan berbicara "atas nama Tuhan", atau bahkan menjadi "corong" Tuhan itu sendiri. Ketika pendakuan absolut ini berkelindan dengan tangan kekuasaan despotik, maka akan ditemukan perselingkuhan agama dengan kekuasaan yang sangat berbahaya.

Selain itu, otoritarianisme juga berakibat pada perlakuan Islam sebagai seperangkat hukum yang mapan, statis dan tertutup, yang harus ditetapkan tanpa menyisakan ruang yang luas untuk pengembangan dan keragaman. Dengan kata lain Islam pada masa modern ini dipandang sebagai seperangkat aturan (ahkām), bukan sebagai sebuah proses pemahaman (fiqh). ${ }^{6}$ Perlakuan tersebut, bagi Khaled, berimplikasi pada punahnya tradisi hukum yang secara kukuh menentang kodifikasi dan penyeragaman. Dan memiliki metodologi hukum yang terbuka dan antiotoritarianisme. ${ }^{7}$

Praktik yang demikianlah yang ditemukan oleh Khaled dalam sejumlah fatwa-fatwa dari sebuah organisasi Islam di Amerika, khususnya fatwa-fatwa yang dikeluarkan oleh CLRO (Council for Scientific Research and Legal Opinions/al-Lajnah al-Da'imah li al-Buhuts al-'Tmiyyah wa al-Ifta', Lembaga Pengkajian Ilmiah dan Fatwa), sebuah lembaga resmi di Arab Saudi. Dari segi perspektifnya, fatwa-fatwa ini menggunakan perspektif Timur Tengah yang dipengaruhi - terutama oleh - puritanisme Wahhabi. Perspektif ini kemudian diterapkan untuk ummat Islam di Amerika. Padahalsebagaimana penjelasan Khaled- keduanya berbeda, dimana masyarakat Muslim di Amerika adalah minoritas sedangkan di Arab Saudi mayoritas. Belum lagi masalah kondisi sosial, budaya, dan sistem pemerintahan. Tentunya hal itu memerlukan proyek

Terj. R. Cecep Lukman Yasin, (Jakarta: PT. Serambi Ilmu Semesta, Cet. 1, 2004), h. 205.

\footnotetext{
${ }^{5}$ Ibid., h. 17.

${ }^{6}$ Ibid., h. 247-248.

${ }^{7}$ Ibid.,
} 
penerapan hukum yang penuh pertimbangan. Mungkin inilah salah satu konstruksi ideologis pemikiran kaum Wahabi yang menyebabkan Khaled berpindah darinya.

Untuk menguatkan kevalidan penelitiannya, Khaled mengumpulkan beberapa fatwa-fatwa CRLO yang dianggap bersifat otoriter bahkan bertendensi misoginis yang menghina dan merendahkan harkat martabat perempuan. Hal itu karena banyak bukti-bukti yang diabaikan oleh organisasi Islam tersebut dan dinilai Khaled sebagai sesuatu yang sangat dangkal, ceroboh dan bahkan penuh dengan ketidakjujuran. Bahkan Khaled melihat tidak adanya kesepaduan, metode, pendekatan yang berlandaskan prinsip moral serta yurisprudensi di dalamnya.Secara ringkas, inilah yang mendasari munculnya gagasan Khaled.

\section{Hermeneutika Otoritatif: Sebuah Solusi}

Menurut analisis Khaled, perangkat hermeneutika adalah solusi dalam menghadapi fenomena otoritarianisme dalam pemikiran Islam, khususnya dalam penelitiannya tentang diskursus hukum Islam. Dan ini merupakan prosedur metodologis terkait dengan relasi antara ketiga unsur pengarang, teks, dan pembaca. Dalam pembacaan Amin Abdullah pendekatan tersebut digunakan Khaled untuk memposisikan bagaimana sesungguhnya hubungan antara teks (text) atau nash, penulis atau pengarang (author), dan pembaca (reader). ${ }^{8}$ Untuk itu Khaled membuat konsepsi baru terkait dengan teks (al-Qur'an dan sunnah), pengarang, dan pembaca.

\section{Al-Qur'an dan Hadits adalah teks terbuka}

Menurut Khaled, al-Qur'an dan Sunnah walaupun berbeda dalam tingkat hirarkinya, haruslah diperlakukan sama. Dalam hal ini, baginya- meminjam istilah Umberto Eco- keduanya adalah karya yang terus berubah. Dalam artian keduanya terbuka untuk berbagai interpretasi. Asumsi yang demikian akan menjadikan teks berbicara dengan suara yang diperbaharui oleh masing-masing generasi pembaca (reader) karena maknanya tidak permanen dan

${ }^{8}$ Amin Abdullah, Pendekatan Hermeneutik dalam Fatwa-fatwa Keagamaan Proses Negosiasi Komunitas Pencari Makna Teks, Pengarang, dan Pembaca, dalam Amin Abdullah, Islamic Studies di Perguruan Tinggi Pendekatan Integratif Interkonektif(Jogjakarta: Pustaka Pelajar, 2006), h. 276. 
berkembang secara aktif. Jadi, sebuah teks akan tetap relevan dan menduduki posisi sentral karena keterbukaannya. Para pembaca akan selalu kembali merujuk kepada teks karena teks dapat menghasilkan pemhaman dan interpretasi baru. ${ }^{9}$

Disini dapat difahami bahwa al-Qur'an dan sunnah menurut Khaled adalah bersifat bebas, terbuka, dan otonom. Ide yang hampir sama juga pernah disampaikan oleh Farid Esack dengan memahami al-Quran sebagai "pewahyuan progresif". ${ }^{10}$ Maka dari itu, untuk menghindari sikap otoriter adalah tetap sadar bahwa teks (al-Quran) merupakan "karya yang terus berubah" atau "wahyu yang progresif". Sehingga segala bentuk penafsiran dan pemahaman akan terus aktif, dinamis dan progresif.

Dalam analisis Khaled, hal inilah yang dibenarkan secara moral. Menurutnya jika teks al-Qur'an dan sunnah diinterpretasi menjadi sebuah makna yang stabil, tetap dan tidak berubah, maka konsekwensinya adalah teks menjadi tertutup dan menyegel maknanya dengan interpretasi pembaca. Secara moral hal ini tidak dibenarkan karena merupakan bentuk kesombongan. Karena seorang pembaca mengklaim memiliki suatu pengetahuan yang identik dengan pengetahuan Tuhan. Dengan demikian seakanakan ia berbicara bahwa interpretasinya identik dengan makna teks yang sebenarnya. Bagi Khaled ini akan berakibat kepada hilangnya otonomi teks, dan secara teologis ini bermasalah karena bersebrangan dengan kemutlakan pengetahuan Tuhan. Al-Qur'an secara tegas menyatakan kemutlakan Tuhan dan pengetahuan-Nya yang tidak bisa disejajarkan dengan pengetahuan siapapun. ${ }^{11}$

\section{Pembaca dan Lima Prasyaratnya}

Walaupun Khaled menganggap al-Qur'an sebagai teks yang bebas, terbuka dan otonom, namun demikian Khaled merasa perlu membatasi otoritarianisme pembaca dengan lima syarat. Prasyarat ini harus dipenuhi atau dilaksanakan. Karena apabila tidak mencukupi, maka pembaca khususnya para wakil khusus

${ }^{9}$ El-Fadl, Atas Nama Tuhan..., h. 212.

${ }^{10}$ Farid Esack, Membebaskan yang Tertindas, Terj., Watung A. Budiman, (Bandung: Mizan, 2000), h. 87.

${ }^{11}$ El-Fadl, Atas Nama Tuhan..., h. 212-213 
atau mujtahid telah melakukan tindakan di luar kewenangan hukum yang dimilikinya (ultra vires). Kelima prasyarat yang menjadi landasan pelimpahan otoritas tersebut adalah sebagai berikut: ${ }^{12}$

Pertama, kejujuran, dimana seorang ahli hukum dituntut tidak bersikap pura-pura memahami apa yang sebenarnya tidak diketahui dan bersikap terus terang tentang sejauh mana ilmu dan kemampuannya dalam memahami perintah Tuhan. Maka dengan demikiran seorang ahli hukum tidak akan menyembunyikan dengan sengaja sebagian perintah Tuhan, atau karena berbagai alasan, sengan sengaja mengganti bunyi perintah-Nya. Dengan kata lain, tidak membatasi, menyembunyikan, berbohong atau menipu, dan menjelaskan semua perintah yang ia pahami.

Kedua, kesungguhan, dimana seorang ahli hukum harus memaksimalkan kemampuan yang ia perlukan untuk mengklaim secara jujur bahwa dirinya telah melakukan semua hal yang bisa dilakukan untuk menemukan dan memahami petunjukpetunjuk yang ada, dan harus bersedia mempertanggungjawabkan tindakannya di hadapan Tuhan pada hari akhir nanti. Di sini Khaled menegaskan bahwa dalam sistem teologi Islam, kewajiban untuk bersungguh-sungguh menemukan dan memahami menjadi lebih besar ketika sebuah hukum bersentuhan dengan hak orang lain. Seseorang bertanggung jawab atas keputusannya yang menyesatkan atau melanggar hak orang lain. Oleh karena itu bagi orang-orang yang berakal, semakin bersentuhan dengan hak orang lain, semakin besar pula keharusan mereka berhati-hati, dan semakin keras upaya mereka dalam melaksanakan kewajibannya terhadap orang lain. Semakin besar pelanggaran mereka terhadap orang lain, semakin besar pula pertanggung jawaban mereka di sisi Tuhan.

Ketiga, kemenyeluruhan, dimana seorang ahli hukum telah mencoba untuk menyelidiki perintah Tuhan secara menyeluruh dan telah mempertimbangkan semua perintah yang relevan, membuat upaya terus menerus untuk menemukan semua perintah yang relevan, dan tidak melepas tanggung jawabnya untuk menyelidiki atau menemukan alur pembuktian tertentu.

${ }^{12}$ Ibid., h. 98-103. 
Keempat, rasionalitas, dimana seorang ahli hukum telah melakukan upaya penafsiran dengan menganalisis perintahperintah Tuhan secara rasional. Tentu saja rasionalitas ini dipandang sebagai sebuah konsep yang abstrak. Namun, bagi Khaled, ia berarti sesuatu yang dalam kondisi tertentu dipandang benar secara umum.

Kelima, pengendalian diri, dimana seorang ahli hukum menunjukkan tingkat kerendahan hati dan pengendalian diri yang layak dalam menjelaskan kehendak Tuhan. Prasyarat ini telah dijelaskan dengan baik dalam ungkapan Islam: "Dan Tuhan lebih tahu yang terbaik (wa Allah a'lam). Ungkapan ini berperan sebagai klaim epistemologis dan moral. Lebih dari sekedar ungkapan, gagasan utama ungkapan itu adalah bahwa seorang ahli hukum harus memiliki kewaspadaan tertentu untuk menghindari penyimpangan atau kemungkinan penyimpangan atas peran Tuhannya.

\section{Negoisaisi antara Teks, Pengarang dan Pembaca}

Konsepsi Khaled mengenai teks al-Qur'an, sunnah dan prasyarat pembaca diatas adalah sebuah konsepsi untuk mewujudkan sebuah negoisasi makna antara pembaca dan teks yang akan dimaknai. Dalam proses negosiasi itu, Khaled menekankan pentingnya latar belakang sosial historis al-Quran. Ia menyatakan wahyu selalu dimediasikan oleh kondisi-kondisi historis yang berlaku. Sehingga, sangat penting untuk menganalisis situasi historis yang menegosiasikan norma-norma etis al-Quran tertentu ${ }^{13}$. Banyak institusi yang diacu dalam al-Quran menurut Khaled hanya dapat dipahami jika pembacanya menyadari praktikpraktik historis yang melingkupi pewahyuan teks tersebut. Namun dengan memisahkan al-Quran baik dari sejarah maupun dari konteks moralnya, maka para penafsir, menurutnya, hanya berujung pada pengubahan teks menjadi daftar panjang perintah hukum yang secara moral tidak jelas. ${ }^{14}$

\footnotetext{
${ }^{13}$ Khaled M. Abou el-Fadl, The Islamic Law of Rebellion, (Cambridge: University
} Press), h. 328

${ }^{14}$ Khaled M. Abou el-Fadl, The Place of Tolerance, (Boston: Beacon Press, 2002), h. 31 
Prinsip negosiasi di atas, sekaligus mengimplikasikan bahwa dalam perspektif hermeneutik, kebenaran pengetahuan tidak pernah bersifat final (the fallibility of knowledge). Karena itulah hermeneutika pada dasarnya tidak menafikan eksistensi dari otoritas, baik itu otoritas teks, pengarang dan pembaca (reader ( audience), akan tetapi melawan segala bentuk dominasi dan monopoli dalam penetapan makna teks. Hermeneutika dalam hal ini berada dalam wilayah publik yang hendak mendialogkan berbagai asumsi kebenaran yang datang dari para pembaca teks. Teks sebagai panduan moral tentu bersifat otoritatif, akan tetapi tatkala direproduksi oleh pembacanya bisa saja ia menjadi otoriter. Inilah yang disebut dengan intervensi pembaca teks (human intervention) dalam penetapan makna teks berdasar interest, atau kepentingan pembacanya.

Negoisasi ini- dalam pandangan Khaled- merupakan bentuk interpretasi otoritatif dengan berdasarkan rasio bukan interpretasi otoriter yang taklid buta, meminjam definisi Joseph Vining. Dimana akan tercipta sebuah gerak interpretasi yang otoritatif, dan terwujud sebuah relasi yang proporsional dan proses negoisasi antara teks, pengarang dan pembaca. Walhal hukum Islam yang dihasilkan tidaklah otoriter dan tidak sewenang-wenang. Negoisasi ini, mungkin dapat digambarkan dengan skema sebagai berikut:

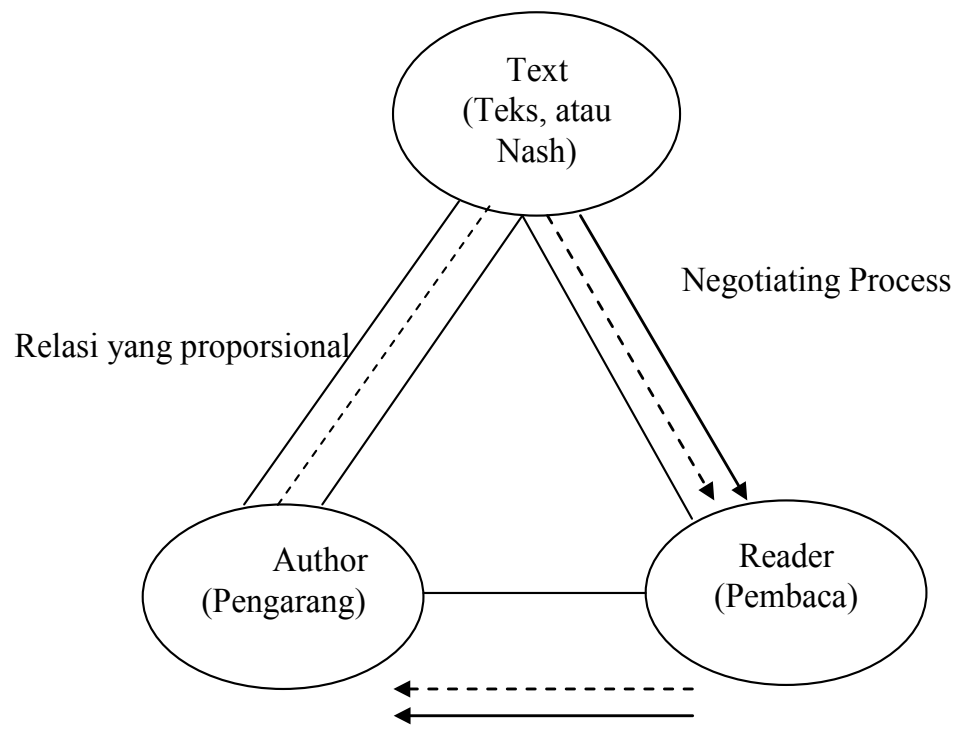


Dari sini dapat disimpulkan bahwa konsepsi pembaca terhadap al-Qur'an dan sunnah sebagai teks yang terbuka, bebas dan otonom adalah upaya untuk menciptakan gerak interpretasi yang dinamis, sehingga tidak ada makna yang bersifat final atau dianggap final. Dan kelima prasyarat yaitu: kejujuran, kesungguhan, kemenyeluruhan, rasionalitas, dan pengendalian diri- harus dimiliki oleh seorang pembaca, dalam artian pembaca teks dalam menghasilkan makna haruslah punya otoritas. Adanya teks yang otonom, dan pembaca yang otoritatif akan menghasilkan relasi dan proses negoisasi yang proporsional sehinga tidak ada lagi pembacaan yang sewenang-wenang dan bertendensi menindas. Kemungkinan inilah yang dimaksud Khaled dengan Hermeunetika otoritatif.

\section{E. Catatan Kritis}

Tawaran Khaled memang cukup menarik, bahkan para pengkaji hukum dari kaum liberal menganggapnya sebagai tawaran metodologi baru dalam hukum Islam. Buku Khaled Speaking ini God's Name: Islamic Law, Authority, and Women diterjemahkan sebagai Atas nama Tuhan: Dari Fiqh Otoriter ke Fiqh Otoritatif. Terjemahan ini, agaknya melihat bahwa gerak hukum fiqh yang berkembang selama ini adalah pemahaman hukum Islam yang bersifat otoriter. Tawaran Khaled- dengan tanpa pembacaan yang kritis- diapresiasi dengan tulisan-tulisan baik dari artikel maupun buku-buku. Namun sebenarnya, tawaran Khaled tersebut mempunyai kelemahankelemahan baik bersifat teoritis dan praksis.

\section{Adanya spirit Gadamerian}

Kalau ditela'ah secara seksama, hermeneutika Khaled sepertinya mengadopsi spirit hermeneutika gadamerian. Hermeunetika ini disandarkan kepada salah seorang tokoh modern Hans Georg Gadamer (1900-2002) dan tergolong ke dalam model hermeunetika subjektif yang memandang teks bersifat terbuka dan dapat diinterpretasikan oleh siapapun. Dalam menafsirkan teks seseorang harus didasari dari apa yang dimilki saat ini (vorhabe), apa yang dilihat (vorsicht) dan apa yang akan diperoleh kemudian (vorgrif)..$^{15}$ Dalam artian, sebuah teks diinterpretasikan berdasarkan

${ }^{15}$ Sumaryono, Hermeneutik: Sebuah Metode Filsafat, (Yogyakarta: Kanisius, 
pengalaman dan tradisi yang ada pada si penafsir itu sendiri dan bukan berdasarkan tradisi si pengarang, sehingga hermeneutika tidak lagi sekedar memproduksi ulang wacana yang telah diberikan pengarang melainkan memproduksi wacana baru demi kebutuhan masa kini sesuai dengan subjektifitas penafsir. Dalam konteks keagamaan, teori ini berarti merekomendasikan bahwa teks-teks al-Qur'an dan sunnah harus ditafsirkan sesuai dengan konteks dan kebutuhan kekinian, dan apa yang dimaksud dengan sebagai $a s b a b$ al-nuzūl dalam al-Qur'an dan asbab al-wurūd dalam sunnah.

Cara pandang ini mirip dengan Hermeneutika Khaled yang memandang al-Qur'an dan sunnah sebagai teks terbuka, dan menekankan pentingnya aspek sosio-historis teks keduanya agar tercipta proses negoisasi makna dan menghasilkan relasi yang proporsional antara pembaca dan teks. Namun demikian, keduanya mempunyai perbedaan; jika dalam hermeneutika gadamerian lebih menempatkan penafsir/ pembaca teks secara dominan, Khaled merumuskan syarat-syarat penafsiran yang terkait dengan prasyarat pembaca sebagaimana dijelaskan sebelumnya. Bahkan Khaled memberi catatan kritis sebagaimana para pengkretik gadamerian seperti Habermas yang menyatakan bahwa hermeneutikanya menganut relativisme dalam artian bahwa makna tidak ada yang pasti.

Namun, rumusan Khaled tersebut mempunyai basis epistemologi yang tidak jauh berbeda dengan Gadamerian. Keduanya menganggap bahwa teks itu bersifat terbuka. Disini, walaupun Khaled membuat prasyarat pembaca sebagai pengawalan namun itu tampak kontradiktif, dimana pernyataanpernyataannya memberikan ruang interpretasi al-Qur'an yang tidak memperhatikan mana yang bersifat tsawābit dan mutaghayyirāt, atau bagian-bagian mana dalam hukum Islam yang diistinbathkan dari al-Qur'an dan sunnah yang sifatnya ushul dan furu'. Contohnya Khaled mempermasalahkan tentang hukum jilbab yang sudah disepakati oleh Ulama tentang kewajibannya, dan mazhab rasional Mu'tazilah sebagai mazhab yang menyeleweng. ${ }^{16}$ Agaknya, Khaled ingin menjunjung Islam sebagai agama rasional, maka dari itu

1993), h. 77.

${ }^{16}$ Khaled M. Abou Fadl, Atas Nama Tuhan... 
klaim bahwa mu'tazilah adalah mazhab yang menyimpang baginya tampak kontradiktif dengan Islam sebagai agama yang rasional.

Konsekwensinya, asumsi Khaled yang menganggap bahwa al-Qur'an dan sunnah adalah teks terbuka akan memunculkan gerak interpretasi yang relatif dengan tinjauan historis, utilitas, dan pertimbangan HAM sebagaimana yang diasumsikan oleh pemikirpemikir liberal seperti Mohammad Arkoun, Nasr Hamid Abu Zayd, Muhammad Shahrur, Abdullah Ahmad an-Na'im, Muhammad Sa'id 'Ashmawi, M. 'Abid al-Jabiri, Fazlur Rahman, Fatima Mernisi, Amina Wadud, Rifat Hassan dan lain-lain. Dan ini mirip dengan spirit gadamerian yang menekankan kontekstualitas makna dalam teks yang dalam hal ini al-Qur'an.

\section{Ukuran Pembaca adalah Rasio}

Sebagaimana telah disinggung sebelumnya bahwa, hermeneutika otoritatif Khaled terfokus pada fatwa-fatwa hukum Islam yang bersifat otoriter. Bagi khaled ini adalah interpretasi otoriter yang taklid buta bukan berdasarkan rasio. Untuk itu dalam ranah fiqh, Khaled mengkampanyekan pentingnya teologi rasional. Ini sesuai dengan mazhab fiqhnya yaitu hanafiyah yang dikenal dengan rasionalitasnya. Namun demikian rasionalitas Khaled tidaklah sama dengan mazhab Hanafi. rasionalitas Khaled didukung sepenuhnya oleh tradisi (konstruksi sosial). Ia menempatkan dirinya dalam tradisi; memanfaatkannya, mengevaluasi dan melakukan kritik terhadap metode fiqh. Daniel W. Brown dalam hal ini menyatakan: ${ }^{17}$

The field of Abou El Fadl's analysis, however, is the hermeneutical tradition of Islamic law. He places himself within that tradition, utilizing, evaluating, and critiquing its hermeneutics and methods.

Dari uraian di atas bisa digarisbawahi bahwa nalar hukum Khaled bercorak nonpositivistik - pengetahuan bersifat subyektif yang bertumpu pada makna, terikat nilai, tidak bersifat linier, dan kebenaran harus diverifikasi lewat pemahaman dan tafsir.

Agaknya, dapat dimengerti bahwa epistemologi Khaled bernuansa apa yang disebut George F. Hourani dengan rationalistic

${ }^{17}$ Daniel W. Brown, A New Introduction to Islam, (Oxford: Blackwell Publishing, 2009), p. 297 
objectivism yang beranggapan bahwa "baik" dan "buruk" bisa diketahui lewat nalar manusia, walaupun tanpa bantuan wahyu. Wahyu dalam hal ini sebatas men-suport dan menkonfirmasi nilai baik dan buruk yang diketahui oleh nalar. Sebuah tindakan dinilai baik dan buruk dalam relasinya dengan maslahah dan mafsadah yang ditimbulkannya. ${ }^{18}$ Dan ini sama dengan para pemikir Muslim liberal lainnya, dan metode Mu'tazilah dalam ranah teologi.

\section{Implikasinya dalam Islam}

Apabila spirit Heremeneutika ini diterapkan maka makna al-Qur'an dan sunnah bersifat relatif, berarti hukum-hukum Islam yang sudah final dapat diubah sesuai dengan konteks sosio-historis kekinian. Disini agar makna al-Qur'an proporsional maka ia harus melebur dengan tradisi (kesadaran sosial) atau dalam istilah Gadamer disebut fusion of horizon. Implikasi dari itu, maka al-Qur'an akan ditafsirkan sesuai dengan tradisi atau subjektifitas penafsir, walhal akan melahirkan warna-warna Islam yang beragam seperti Islam Kejawen, Islam Indonesia, Islam Demokrasi, Islam Moderat, tidaklah sesuai dengan pandangan-alam Islam. (Islamic worldview). ${ }^{19}$

Selain itu, penitikberatan Khaled pada konteks sosio-historis menjadikan makna dan petunjuk-petunjuk lafadz al-Quran yang pada masa turun wahyu adalah hakikat, berubah menjadi makna metafor (majaz). Artinya hakikat-hakikat petunjuk al-Quran bisa dilipat dalam gulungan dan lembaran sejarah.

Sebenarnya, pernyataan khaled tersebut mendapatkan bantahan dari temannya sendiri, yaitu Akeel Bilgrami ${ }^{20}$. Bilgrami mengatakan bahwa pemahaman historis Khaled memang masuk akal dan juga menarik, tetapi hal itu hanya merupakan pernyataan tanpa argumentasi, dan tentu akan menemui pernyataan tandingan -oleh orang muslim yang pada dasarnya, tidak menerima kontekstualisasi historis apa pun terhadap al-Quran, dan juga oleh para kritikus Barat yang tidak mempunyai simpati yang diperlukan untuk menerima

${ }^{18}$ Lihat: Abid Rohmanu, Konsepsi Jihad Khaled M. Abou El Fadl dalam Perspektif Relasi Fikih, Akhlak dan Tauhid. (Disertasi). (Surabaya: IAIN Sunan Ampel, 2010), p. 32

${ }_{19}$ Adnin Armas, Filasafat Hermeneutika dan Dampaknya Terhadap Studi AlQuran. H. 28-29. Bisa download di h t t p : / / w w w . in s i s t n e t . c o m

${ }^{20}$ Akeel Bilgrami adalah professor Johnsonian dalam bidang ilmu filsafat di Columbia University. 
kontekstualisasi tersebut ${ }^{21}$. Di samping itu, pernyataan Khaled di atas akan menimbulkan konsekuensi yang rumit untuk diterima akal sehat. Apakah dengan demikian Tuhan tunduk mengikuti kaidah peraturan alam yang diciptakan-Nya sendiri? Apakah kemudian wahyu dapat dipaksa untuk mengikuti kemauan realitas sejarah?

Selain itu, apabila spirit Heremeneutika ini diterapkan maka mengharuskan relatifisme penafsiran terus-menerus. Maka dari itu, tafsir yang sudah dihasilkan oleh para mufassir terkemuka harus selalu direvisi. Dampak dari penggunaan hermeneutika ini akan menggugat hal-hal yang sudah mapan dalam penafsiran al-Qur'an. Dalam sejarah ilmu tafsir, mufassir al-Qur'an tidak selamanya terpengaruh dengan tradisi, latar-belakang sosial dan budayanya. Fakta bahwa mufassir dari zaman ke zaman, lintas waktu dan ruang, namun tetap memiliki kesamaan pendapat, menunjukkan refleksi mufassir menembus relatifitas penafsiran.

Paham relatifisme tafsir ini sangat berbahaya, sebab: (1) Menghilangkan keyakinan akan kebenaran dan finalitas Islam, sehingga selalu berusaha memandang kerelatifan kebenaran Islam, (2) menghancurkan bangunan ilmu pengetahuan Islam yang lahir dari al-Quran dan Sunnah Rasul yang sudah teruji selama ratusan tahun. Padahal metode hermeneutika al-Quran hingga kini masih merupakan upaya coba-coba para ilmuwan kontemporer yang belum membuahkan pemikiran Islam yang utuh dan komprehensif. Akibatnya, para pendukung hermeneutika tidak akan mampu membuat satu tafsir al-Quran yang utuh. Mereka hanya berkutat pada masalah dekonstruksi sejumlah konsep / hukum Islam yang sudah di pandang baku dalam Islam, dan (3) menempatkan Islam sebagai agama sejarah yang selalu berubah mengikuti zaman. ${ }^{22}$

Dengan demikian, posisi penafsir yang ideal adalah hendaknya sampai pada pemahaman yang yakin dan dipercayai sebagai maksud pembicara yang sebenarnya. Namun, keyakinan itu tidak dapat datang dalam semua kondisi, tetapi dalam kondisi semantik teks yang secara jelas menunjukkan maksud. Kondisi ini adalah kandisi yang bisa disebut dengan istilah "an-nash". Dalam

${ }^{21}$ Khaled, The Place of Tolerance..., p. 81

${ }^{22}$ Adian Husaini, Hermeneutika dan Tafsir Al-Quran, (Jakarta: Gema Insani, 2007), p. 20 
teks-teks keagamaan, seorang penafsir berusaha untuk memahami nash yang biasa diistilahkan "zhahir", meskipun penafsir di sini tidak dapat yakin bahwa makna yang telah digapainya adalah makna yang final dan pasti bagi teks, tetapi ketidak yakinan ini tidak berarti menghilangkan penafsiran dari nilai objektivitas dan nilai. Kegundahan dan kesulitan untuk mencapai secara penuh pemahaman yang sesuai dengan kenyataan atau dengan kehendak pembicara bukan berarti tidak ada tolak ukur untuk meneliti keshahihan dan kesalahan penafsiran ${ }^{23}$.

Secara aplikatif, spirit hermeneutika yang dikampanyekan Khaled tadi dapat dilihat dari penafsirannya mengenai makna qawwamun dalam surat an-Nisa, ayat:

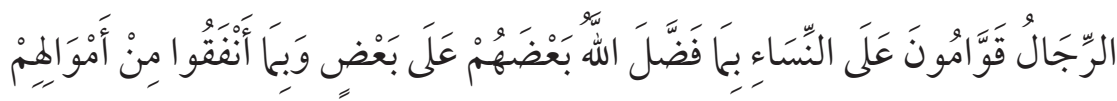

Kaum laki-laki itu adalah pemimpin bagi kaum wanita, oleh karena Allah telah melebihkan sebagian mereka (laki-laki) atas sebagian yang lain (wanita), dan karena mereka (laki-laki) telah menafkahkan sebagian dari harta mereka.

Menurut Khaled, kata qawwāmān mengandung beragam terjemahan sesuai dengan cara kata tersebut dipahami dan diinterpretasikan. Kata tersebut bisa berarti "pelindung, pendukung, penguasa atau pelayan" dalam kesemuanya itu, pasal pentingnya adalah bahwa ayat tersebut tidak menentukan hubungan laki-laki dan perempuan dengan cara yang absolut dan tidak bergantung. Sebaliknya ayat tersebut menurut Khaled, secara eksplisit menyatakan bahwa apa pun statusnya -apakah sebagai pelindung atau pendukung- ia adalah status yang bergantung pada aksi manusia (yaitu "sesuai dengan kekayaan yang dinafkahkan untuk yang lain") dan bergantung pada tindakan Tuhan (yaitu, dengan kelebihan yang Allah anugrahkan kepada seseorang di atas seseorang yang lain). ${ }^{24}$

Selain itu kata fadhdhola yang dengan ragam derivasinyadalam al-Qur'an- bermakna suatu anugrah atau preferensi fisik

${ }^{23}$ Fahmi Salim, Kritik Terhadap Studi al-Quran Kaum Liberal, (Jakarta: Perspektif, 2010), p. 61-62

${ }^{24}$ Khaled, Selamatkan Islam dari Muslim Puritan. Terj. Helmi Mustofa, (Jakarta: Serambi, 2006), p. 320-321 
dan spiritual yang dilimpahkan oleh Tuhan, baik sebagai ganjaran atas amal kebajikan maupun sebagai tindak penganugrahan. Jika diteliti lima puluh ayat al-Quran yang menggunakan kosakata fadhl, maka akan ditemukan fakta yang nyata bahwa baik pahala maupun anugrah Tuhan, keduanya bisa diperoleh oleh siapa pun yang mencarinya. Dengan pemahaman ini, kita bisa mengerti bahwa laki-laki dan perempuan sama-sama memenuhi syarat untuk memperoleh anugrah dan pahala dari Tuhan. otoritas yang diberikan kepada laki-laki di atas perempuan tidak dikarenakan mereka adalah laki-laki, tetapi karena dalam kesejarahan tertentu, laki-laki secara finansial menafkahi perempuan. Namun, bila kondisi berubah, dan perempuan memiliki tanggung jawab financial yang sama dengan laki-laki, otoritas harus dibagi secara adil di antara keduanya ${ }^{25}$.

Hal ini tentunya berbeda dengan para mufassir, seperti alThabari yang menafsirkan "ar-rijālu qawwāmūna 'ala al-nisā" adalah kaum laki-laki berfungsi sebagai pendidik dan pembimbing bagi para isteri dalam melaksanakan kewajiban terhadap Allah SWT dan kewajiban terhadap para suami sendiri. Hal ini pula yang menjadi sebab keutamaan laki-laki atas wanita, seperti tercermin dalam lafadz wabimā anfaqu min amwālihim, yaitu kewajiban membayar mahar, nafkah dan kifayah. ${ }^{26}$ Lebih lanjut al-Thabari menjelaskan keutamaan laki-laki ditinjau dari sudut kekuatan akalnya serta kekuatan fisiknya sehingga kenabianpun menjadi hak bagi lakilaki. Dengan kekuatan fisik dan akalnya inilah al-Imāmah al-kubra yaitu menjadi khalifah dan al-Imāmah sugra seperti menjadi imam shalat. ${ }^{27}$

\section{F. Penutup}

Dari pemaparan di atas dapat disimpulkan bahwa heremeneutika Otoritatif Khaled berdiri di atas beberapa kritertia: pertama, mengasumsikan al-Qur'an dan Sunnah sebagai teks terbuka, dalam artian makna al-Qur'an harus dinamis dengan interpretasi. Kedua, heremeneutika otoritatifberarti penafsiran yang berdasarkan

${ }^{25}$ Ibid, p. 321

${ }^{26}$ Ath-Thabari, Jami al-Bayan fi tafsir ayyil Qūran, (Mu'assasah ar-Risalah, Cet. 1, 2000), Juz. 8, p. 290

${ }^{27}$ Ibid. P. 291 
dengan rasio dan ini menurut Khaled sesuai dengan semangat Islam sebagai agama yang rasional. Ketiga, walaupun bersifat terbuka dan rasional, seorang penafsir harus mempunyai prasyarat yaitu: kemenyeluruhan, kesungguhan, kejujuran, rasionalitas dan pengendalian diri. Dari kriteria tersebutlah akan terwujud sebuah model pembacaan yang negoisatif dan penempatan yang proporsional antara teks, pengarang dan pembaca, sehingga otoritarianisme tidak terjadi.

Namun demikian secara implisit, tawaran Khaled mengandung semangat Hermeneutika Gadamerian yang membaca teks secara subjektif, walaupun Khaled membuat prasyarat pembaca sebagai pengawalan namun itu tampak kontradiktif, dimana pernyataan-pernyataannya memberikan ruang interpretasi alQur'an yang tidak memperhatikan mana yang bersifat tsawabit dan mutaghayyirat, atau bagian-bagian mana dalam hukum Islam yang diistinbathkan dari al-Qur'an dan sunnah yang sifatnya ushul dan furu'. Ini dapat dilihat ketika perangkat yang ditawarkan Khaled dipraktikan dalam membaca beberapa ayat-ayat hukum, dimana Khaled lebih mengedepankan rasionalitas daripada aturan-aturan wahyu yang dijelaskan oleh sunnah kenabian dan disepakati oleh Ijma'. Implikasinya kebenaran interpretasi tidaklah bersifat final, namun relatif. Dari itu, dapat disimpulkan bahwa tawaran hermeneutika Khaled agaknya tidak mengarah pada interpretasi yang otoritatif, tetapi malah mendekonstruksi struktur dan metode pengkajian teks al-Qur'an dan as-Sunnah, walhal ini akan menghasilkan hukum-hukum yang dekonstruktif dan tunduk pada nuansa zaman. Dan ini tentunya keluar dari framework Islam dalam membaca teks. [.]

\section{Daftar Pustaka}

Abdullah, Amin, Islamic Studies di Perguruan Tinggi Pendekatan Integratif Interkonektif, Jogjakarta: Pustaka Pelajar, 2006.

Armas, Adnin, Filasafat Hermeneutika dan Dampaknya Terhadap Studi Al-Quran. H. 28-29. Bisa download di http://www. insistnet. com 
Al-Thabari, Jamì al-Bayān fi Tafsìr Ayyil Qur'an, Mu'assasah ar-Risalah, Cet. 1, 2000.

Brown, Daniel W., A New Introduction to Islam, Oxford: Blackwell Publishing, 2009.

Daud, Wan Mohd Nor Wan, Filsafat dan Praktik Pendidikan Islam Syed M. Naquib Al-Attas, terj. Hamid Fahmi, dkk., Bandung: Mizan, 2003.

Esack, Farid, Membebaskan yang Tertindas, Terj., Watung A. Budiman, Bandung: Mizan, 2000.

Hidayat, Komaruddin, Memahami Bahasa Agama: Sebuah Kajian Hermeneutika, Jakarta: Paramadina, 1996.

Husaini, Adian, Hermeneutika dan Tafsir Al-Quran, Jakarta: Gema Insani, 2007.

Kamus Bahasa Indonesia, Pusat Bahasa Departemen Pendidikan Nasional: Jakarta, 2008.

El-Fadl, Khaled M Abou, Atas Nama Tuhan: Dari Fikih Otoriter ke Fikih Otoritatif, Terj. R. Cecep Lukman Yasin, Jakarta: PT. Serambi Ilmu Semesta, Cet. 1, 2004.

El-Fadl, Khaled M Abou, The Islamic Law of Rebellion, Cambridge: University Press.

El-Fadl, Khaled M Abou, The Place of Tolerance, (Boston: Beacon Press, 2002.

El-Fadl, Khaled M Abou, Selamatkan Islam dari Muslim Puritan. Terj. Helmi Mustofa, Jakarta: Serambi, 2006.

Mushlih, Muhammad, Filsafat Ilmu: Kajian atas Asumsi Dasar Paradigma dan kerangka Teori Ilmu Pengetahuan, Yogyakarta: Belukar, Cet. V, 2008.

Rohmanu, Abid Konsepsi Jihad Khaled M. Abou El Fadl dalam Perspektif Relasi Fikih, Akhlak dan Tauhid, (Disertasi), Surabaya: IAIN Sunan Ampel, 2010.

Saeed, Abdullah, Interpreting the Qur'an: Towards a Contemporary Approach, London and New York, Routledge, 2006.

Salim, Fahmi, Kritik Terhadap Studi al-Quran Kaum Liberal, Jakarta: Perspektif, 2010.

Sumaryono, Hermeneutik: Sebuah Metode Filsafat, Yogyakarta: Kanisius, 1993. 
Muhammad Sofyan 